\title{
MICRO WORLDS: LEARNING ABOUT PROBABILITIES IN SIMULATED CONTEXTS
}

\section{MICRO MUNDOS: PROBABILIDADES DE APRENDIZAGEM EM CONTEXTOS SIMULADOS}

\section{MICRO MUNDOS: APRENDIZAJE DE LAS PROBABILIDADES EN CONTEXTOS SIMULADOS}

\author{
Angel Salvatierra Melgar ${ }^{1}$ (D) José Nieto Gamboa² (D) César Daniel Escuza Mesías $^{3}$ (D), \\ Paola Gissella Orozco-Vargas ${ }^{4}$ (D), Linda Shardin-Flores ${ }^{5}$ (D)
}

\footnotetext{
${ }^{1}$ Universidad Nacional Mayor de San Marcos. Lima, Peru.

${ }^{2}$ Universidad Nacional Mayor de San Marcos. Lima, Peru.

${ }^{3}$ Universidad Nacional Mayor de San Marcos. Lima, Peru.

${ }^{4}$ Universidad César Vallejo. Trujillo, Peru.

${ }^{5}$ Universidad Continental. Lima, Peru.
}

Corresponding author:

Angel Salvatierra Melgar

Email: asalvatierram@unmsm.edu.pe

How to cite: Melgar, A. S., Gamboa, J. N., Mesías, C. D. E., Orozco-Vargas, P. G., \& Shardin-Flores, L. (2021). Micro worlds: learning about probabilities in simulated contexts. Revista Tempos e Espaços em Educação, 14(33), e15122. https://doi.org/10.20952/revtee.v14i33.15122

\begin{abstract}
In this study, the learning processes of the concepts of the probability topic are based on the use and simulation of the micro world tools by the learning actors, who demonstrated creativity, selection of the objects visible in the interface, and the introduction of basic programming principles associated with the topic in question. For the development of the study, we proceeded by the experimental design of a pre-experimental type of an intact group made up of 50 students from the 5 th academic semester of the Professional School of Education of a Public University. The data were collected by an academic test before and after the experimentation, to later be processed and analyzed through the Student's t-statistic expression for related samples, reaching the following conclusion. The experimentation with micro worlds as active learning strategies based on the theory of constructionism, presents a high degree of interactivity associated with sounds, silhouettes, graphics and activities, which allowed to promote the conceptualization, resolution of exercises and problems of the topic in an experiential way in environments natural simulated by the computer. Keywords: Probabilities. Active learning. Micro worlds. Information and communication technology.
\end{abstract}




\section{RESUMO}

Neste estudo, os processos de aprendizagem dos conceitos do tema probabilidade são baseados no uso e simulação das ferramentas do micro mundo pelos atores da aprendizagem, que demonstraram criatividade, seleção dos objetos visíveis na interface e introdução da programação básica princípios associados ao tema em questão. Para o desenvolvimento do estudo procedeu-se ao desenho experimental de um tipo pré-experimental de um grupo intacto constituído por 50 alunos do 5o semestre letivo da Escola Profissional de Educação de uma Universidade Pública. Os dados foram coletados por meio de um teste acadêmico antes e após a experimentação, para posteriormente serem processados e analisados por meio da expressão da estatística t de Student para amostras relacionadas, chegando-se à seguinte conclusão. A experimentação com micro mundos como estratégias ativas de aprendizagem baseadas na teoria do construcionismo, apresenta um alto grau de interatividade associada a sons, silhuetas, gráficos e atividades, o que permitiu promover a conceituação, resolução de exercícios e problemas do tema de forma vivencial forma em ambientes naturais simulados pelo computador.

Palavras-chave: Probabilidades. Aprendizagem ativa. Micro mundos, Tecnologia da informação e comunicação.

\section{RESUMEN}

En el presente estudio, se fundamentan los procesos del aprendizaje de los conceptos del tópico de probabilidades durante el uso y simulación de las herramientas del micromundo por los actores del aprendizaje, quienes demostraron creatividad, selección de los objetos visibles en la interfaz, y la introducción de principios básicos de programación asociado al tópico en referencia. Para el desarrollo del estudio, se procedió por el diseño experimental de tipo preexperimental de grupo intacto conformado por 50 estudiantes del quinto semestre académico de la escuela profesional de educación de una universidad pública. Los datos fueron recogidos por una prueba académica antes y después de la experimentación, para luego ser procesado y analizado a través de la expresión estadística t de Student para muestra relacionadas, con lo que se arribó a la conclusión siguiente: la experimentación con los micromundos como estrategias activas del aprendizaje fundamentado en la teoría del construccionismo presenta alto grado de interactividad asociado a sonidos, siluetas, gráficos y actividades, que permitió promover la conceptualización, resolución de ejercicios y problemas del tópico de manera vivencial en entornos naturales simulados por el computador.

Palabras clave: Probabilidades. Aprendizaje activo. Micro mundos. Tecnología de la información y la comunicación.

\section{INTRODUCTION}

In today's scenarios, information and communication technology (ICT) is inserted in different areas of human development, such as business productivity, administration, and education, among others. The actions were developed within the educational scenarios in order to understand, apply and solve problematic situations of the topic of probabilities. Due to the great subjective, abstract and uncertain complexity of the topic, we proceeded to the elaboration of computational micro worlds associated to the thematic concepts for significant learning.

This learning tool is part of the web 2.0, which interacts with a programming language of Logo syntax. In its interface there are objects with commands for movements, sounds, texts, designs that allow the elaboration or simulation of natural scenarios such as landscapes, cities, ecosystems, among others. For this purpose, athletic race tracks and landscapes were generated for the simulation of horse games, which allowed a significant and active understanding of the conceptual components of the theme from this perspective (Saxe \& Murillo, 2011).

Computer-assisted learning is a cultural seed in the way users think. Under this position, Papert (1995) argues the importance of virtuality in learning, exposes its constructionist model. The 
student is an active entity in learning, designer of his own projects and constructor of his learning using virtual tools.

On the constructionist position, the student is the one who addresses the computer according to their needs. It is there where he demonstrates his mastery over it, ceasing to be an information consumer. One of the tools that allows this constructivist interactivity is the microworld with the characteristics described.

For Aguirre (2018), the micro world is an excellent didactic resource for interactive and constructionist learning in natural scenarios designed by the computer, because of its active, representative and collaborative form; it allows the student to learn thematic concepts from the construction of micro worlds and the association in the game in diverse natural realities simulated by the computer in themes of classic probabilities.

On the other hand, for Álvarez et al. (2015), the manipulation of the resource and the use of virtual tools generate and wake up competitiveness and productivity in their performance, where the main activity of the student is to select the objects lodged in the interface and the construction of varied scenarios and simulating with real thematic contents from their own concepts and experience.

Under this perspective, the teacher becomes a direct witness of the quantitative and qualitative changes of the students' learning, because micro-worlds are constructivist pedagogical tools that simulate the real world in the computer, and allow students to make decisions, analyze cases, make mistakes and propose solutions to the determined problem in a computer environment, with an attractive and easy to manipulate interface. The combination of virtual tools and games recreates a simulated environment of the concrete reality in a computer.

\section{LITERATURE REVIEW}

With respect to the probabilities, they represent uncertainties practiced since ancient times, due to the desire of man to know, identify with certainty the facts or events that could happen in the future. For Ortiz \& Alsina (2017), the subject is an indispensable support for making decisions applied in any area of our daily practice. Moreover, by nature, the human being has always been stubborn in the search for truth from the empirical facts to the professional.

This discipline has gained importance within statistics; today it is known as probability theory, because of its usefulness and transcendence; it was established in the curriculum of several professional training courses, as is the case in the training of teachers in the faculties of education of universities.

Restrepo \& González (2003) reviewed the historical and transcendental contributions of one of Blaise Pascal's (1623-1662) trips, in which the French mathematician met Antoine Gombaud, a knight of Meré, an enlightened man and passionate player of cards and dice.

This man thought he had found a "falsehood" in the numbers during the game with the dice; he observed the behavior of the dice: it was different when using one die than when using two. The "falsehood" was shown in the erroneous comparison between the probabilities of getting a six with one die or getting a six with two dice; the point was that Gombaud did not take into consideration that in the second event he was analyzing a compound probability.

The case was reported to Fermat, who commented that Caballero de Meré was very talented. Then it was Pascal and Fermat who formalized the theory of probability from Meré's statement of falsity. In the university context, it is treated from the intuitive meaning of the classical probabilities, of frequency and of subjectivity in an axiomatic way, through events before and after in random experiments, which entails its ambiguity.

Resorting to the described arguments, the study shows the importance in the interaction of the use of digital tools in the construction of virtual scenarios in the computer called micro worlds, 
as in the case of landscapes, cities, diversity of habitat. For the specific case, simulations of athletic tracks, tracks for horse games, which were part of the research for the understanding and acquisition of concepts of the uncertainties in real scenarios elaborated by the actors of learning. In addition, these practices gave off creativity from the users in the decorations of the scenarios, in the intrinsic initiatives, in the detachment of the logical thought during its elaboration.

\section{METHODOLOGY}

This study is based on the quantitative approach, which was used in the pre-experimental design. According to Cruz et al. (2018), the observation of the response variable before and after the strategic use of the micro world exposed to the 50 students of the fifth academic semester in the professional school of education of a public university was possible thanks to the instruments of the academic test under the observation technique, which was applied before and after the experimental actions, which lasted four weeks in a total of 20 academic hours; the actions began with a previous evaluation on the topic of probabilities, then, after the indications given to the students in the computer laboratory, the micro worlds were elaborated in the computer associated to natural situations, contextualized to their professional training, where thematic representations related to the topics of probabilities could be highlighted. The data processing and analysis were carried out through descriptive and inferential statistics, which allowed the contrasting of the hypothesis thanks to the Student's t-parametric test for related samples of the group.

\section{Development}

Currently, ICT are immersed in the different processes of human activity and productivity, which facilitates interactivity with professionals in different circumstances and regardless of location. Within the field of education, it has managed to insert itself as a necessary good in the processes of teaching and learning as a didactic resource, in addition it is a curricular content of general formation that is given during the professional training in some careers. The use of ICT in learning allows the strengthening of virtual skills and competencies, responsible interaction, leads to access to sufficient information in certain areas of knowledge, also to the manipulation and interaction with programs, interactive videos, use of platforms, electronic calculators, simulators, use of open databases for their respective reporting of results.

As a process for teaching, it allows the teacher to interact with data and relevant information, visualization of educational videos, use of platforms for the process of hybrid teaching between the face-to-face and non-face-to-face phase. The teacher's role in these scenarios changes to that of a facilitator or page guide for access to information. In these scenarios, the teacher learns together with the student and shares acquired experiences.

The developed experimentation was supported by the free and open access tool hosted in Google web 2.0; its main feature is the interactivity with the student during its manipulation and elaboration of virtual scenarios; it consists of a great amount of pre-designed objects, which allows the construction of landscapes, natural and social spaces, ecosystems, among others, and the insertion of movements, texts, dialogues and sounds. In these scenarios, the student becomes a constructor of his thought and learning, since each object presented rationally responds to real situations that the student represents according to his experience.

Quintero (2009) considers micro-worlds as didactic mediators by the visual representation of knowledge in the process of interaction with the student, who promotes construction skills, reasoning, propositional sentences close to reach, logical sequences and procedures, detachment of imagination and creativity during its elaboration and selection of objects.

The experiment was developed within the subject of statistics applied to education in topics of algebraic probabilities. Due to its subjective and sterile content for the student of professional 
careers related to the social sciences, it was agreed with the students the experimentation with the micro-worlds as a means to understand the topic, inserting concepts of experiment, sample spaces, events and the calculation of the classic probabilities. During the experimentation and elaboration, the students represented their products alluding to concepts acquired during their professional training. Students from the specialties of early childhood education, elementary education, history and geography, and language and literature showed greater enjoyment in terms of thematic presentation according to the concepts acquired, combination of objects, colors, and moving ecosystems of characters and animals.

While the students of the specialties of mathematics and physics showed attachment to the formalization of the concepts of the classic probabilities, like events, determination of the probabilities in the competition of races and programs for the event in games of horses, athletes, simulated in race tracks for the identification of the success during the competition.

Figure 1. Micro world presented by an early childhood student.

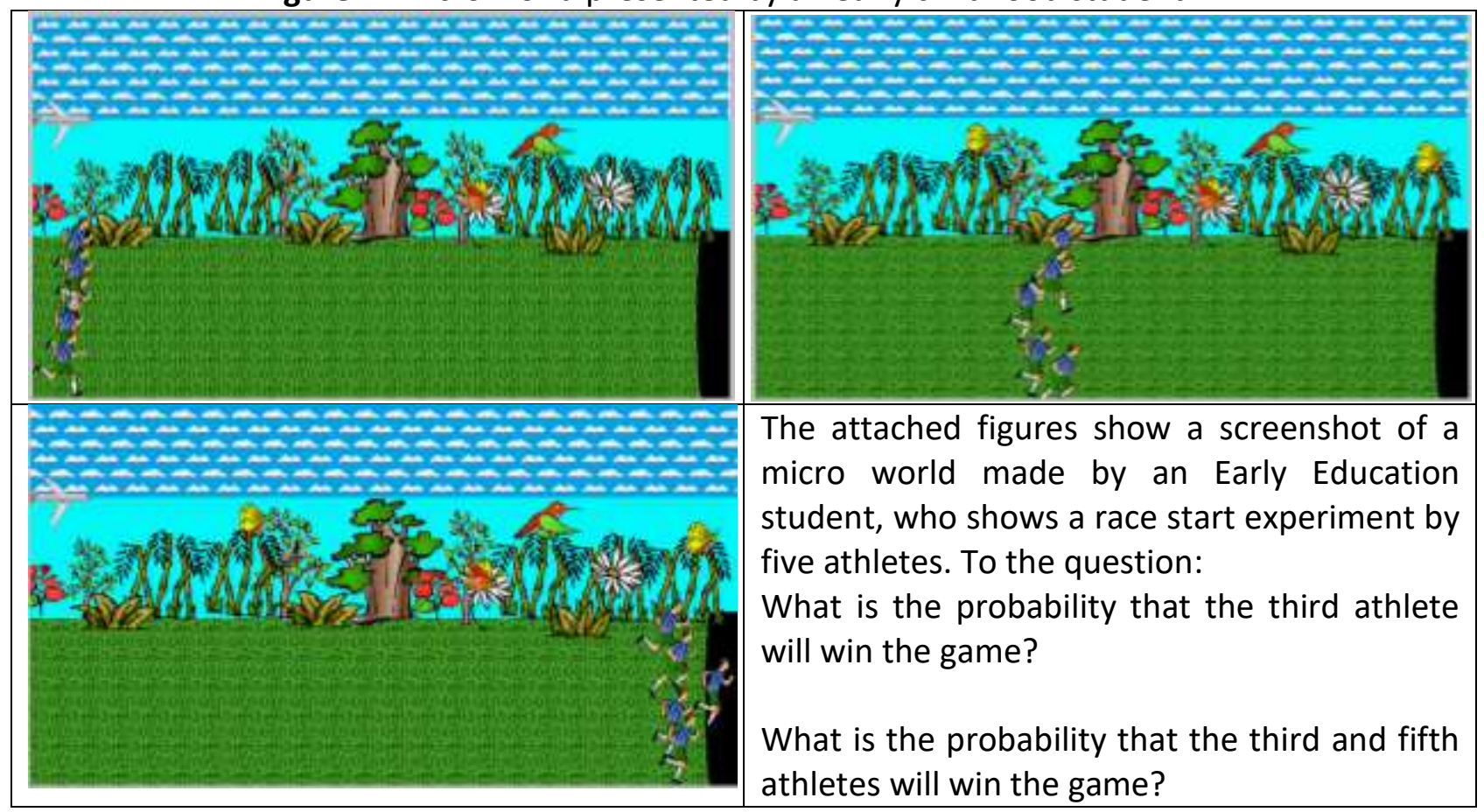

The three screenshots shown represent a thematic micro world of a race competition for five athletes. As can be seen, the amount of decorative elements show the representative concepts from their professional training by displaying moving objects, colorful silhouettes, in this respect, Ospina (2016) states that a pre-school teacher, predisposes the actions that allow her to act on the child.

The future student teachers, due to their training and peculiar characteristics of attachment to the children, show and show the value affection to the social and emotional development of the children, showing the beauty of the objects in class, teaching materials for the different areas, fine psychomotor activities, with the purpose of awakening the attention and interest of the children.

For Cabrera (2011), it is a priority in a preschool child, the promotion of cognitive, affective and social aspects, in addition to the promotion of a psychosocial environment, which allows the promotion of academic talent.

These actions, inherent to the teacher, allowed her micro-worlds presentations to emerge, which showed more detail than requested. Not only is the experiment observed in the departure of athletes, but also the scenarios are shown demonstrating creativity and the strengthening of logical thinking during interactivity. 
Figure 2. Micro world presented by student from the Professional School of Mathematics and Physics

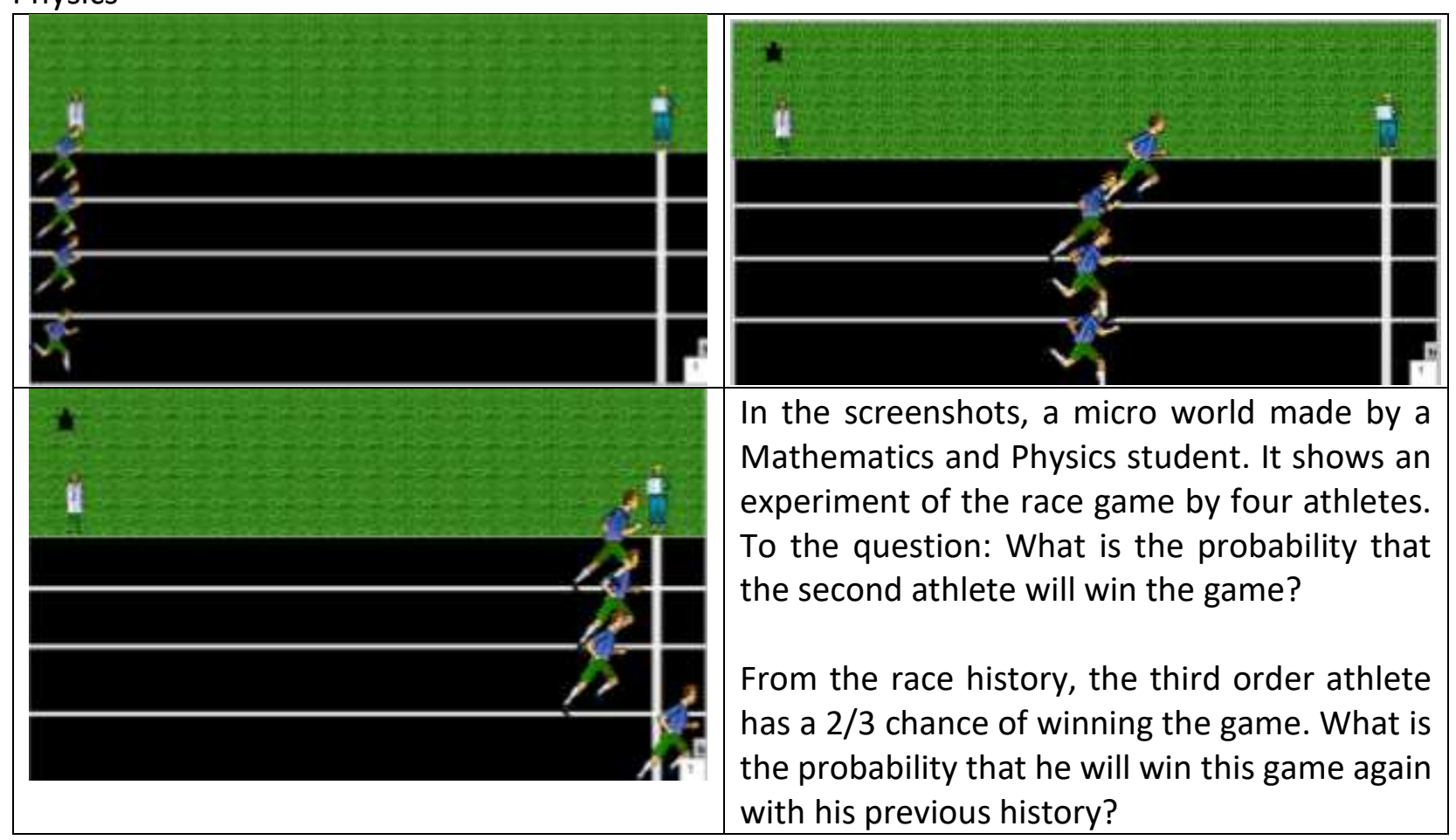

The sequence presented in the image captures of the scenarios elaborated by a student of the professional school of mathematics and physics; they showed more attention to the conceptual content of probabilities, with technical details incorporated such as the marked race track, the referee who issues the order for the start, as well as the judge who controls the arrival to the final straight accompanied by a data record for the taking of the times.

Jiménez \& Gutiérrez (2017) make reference to the formation of the student's mathematical concepts, which is due to internal factors such as affinity, personality, family background and practical knowledge, and to external factors such as school situation, parents or experiences with educational authorities.

After the experimentation, we can state that the way the teacher approaches and teaches has a great influence on his or her style and way of presenting the thematic scenarios designed for experiential learning in virtual environments, as a result of professional training, academic interaction, the environment where he or she develops professionally, and the interactions among peers during pedagogical practice.

After the representation and programming of the objects in the scenarios, the students proceeded to enunciate various cases regarding the arrival of their favorite athletes to their destination, and then simulate the events by inserting the concepts of probabilities. It was observed that the students showed greater interactivity, participation and communication among the participants of each group. The Faculty of Education of the University, organically structured by the different heads, areas and professional schools, organizes events at the end of each academic semester such as achievement presentations, researches made by the students, thematic presentations, case demonstrations called university extension.

During the experimentation, a group made up of five students, the coordinator states: "Below is the scenario of the micro world that represents the race competition with five athletes, it has been identified that the last three athletes are older than 24 years and the other two are younger than the indicated age. 
In addition, the type of intake during their physical preparation has been identified as: high in carbohydrates, high in sugar, supply of PVM concentrate, supply of high-calorie foods and natural consumption". With these guidelines, they asked their 50 classmates to express their preference for their favorite athlete under the indicated conditions, and after five minutes each one of them expressed their preference for success and was registered. Which of the athletes, under the indicated conditions, has the probability of winning the race?

Answers were given and organized in the table below.

Figure 3. Systematization of preferences during competition in the micro world

\begin{tabular}{|c|c|c|c|c|c|c|}
\hline & \multicolumn{5}{|c|}{ TYPE OF INTAKE } & \multirow{2}{*}{ Total } \\
\cline { 2 - 7 } & $\begin{array}{c}\text { High in } \\
\text { carbohydrates }\end{array}$ & $\begin{array}{c}\text { High in } \\
\text { sugar }\end{array}$ & Supply & $\begin{array}{l}\text { High in } \\
\text { calories }\end{array}$ & $\begin{array}{l}\text { Natural } \\
\text { Sonsumption }\end{array}$ & \\
\hline Over 24 years old & 6 & 8 & 4 & 6 & 2 & 26 \\
\hline Not older than 24 years & 4 & 6 & 8 & 4 & 2 & 24 \\
\hline Total & 10 & 14 & 12 & 10 & 4 & 50 \\
\hline
\end{tabular}

The data recorded in the table represents the athlete's gain preference in the game issued by the 50 participants in the classroom; the figure shows the responses, greater than 24 years with high carbohydrate intake, so it was no greater than 24 years with normal food! This allows the collection of data of the joint frequencies; we proceeded to finish the marginal and total data. As a result of the data recorded in the table, probabilities were calculated such as what is the probability that the athlete with high sugar intake will be the winner, what is the probability that the athlete not older than 24 years will be the winner? Likewise, the additive probabilities were calculated: what is the probability that the athlete who is older than 24 years old or has a high caloric intake will win the competition?

Finally, as a conditional probability, if the athlete is older than 24 years old, what is the probability that the athlete who shows high carbohydrate intake wins the competition, among other statements obtained from the table exposed.

The classic concept of probability considers the proportion of the cardinality of the favorable event to the number of possible cases, provided that all the results are equally probable. For Molina (2016), probability (aleae in Latin) contrasts with the uncertainty in games, from the quantitative approach it gains strength in numerical calculations that was quite fast and depended on an apparently very simple concept.

However, the actions developed in the experimentation allowed to understand the topic under the assumptions of competitions, active participation, and games during learning, and motivation during the participation of the simulations with the micro worlds.

These activities allowed the student the familiarization and the perception in an objective way to the comprehension of axioms of the topic, that very frequently the student shows difficulty of learning by its abstract magnitude, representing this one of the factors of interruption of its studies or postponement to the development of the subject. In this regard, Camacho et al. (2018) identify three risk dimensions associated with student abandonment and desertion due to the complexity of curricular experiences.

The first refers to student performance, the second dimension to commitment to the institution, and the third dimension to school behavior. In university classrooms, it is common for students to drop out or withdraw temporarily due to the complexity of some topics in mathematics, physics, chemistry, and statistics unless the student presents previous knowledge such as uncertainties. 
The elaboration of the micro worlds as a learning strategy for the students has allowed the understanding of the concept and the use of the probabilities during the curricular experience of the statistics. Self-regulation and spontaneous creativity during the selection of the elements available in the interface allowed the promotion of logical thinking during the generation of movements programmed by the Logo language. For Viteri et al. (2011), micro worlds are tools with constructivist support that simulate the real world in the computer, where the student analyzes procedures, makes decisions, learns by trial and error a situation of events in a computer environment.

This experimentation and obtained results generated the reformulation of its mental scheme and model, since the interaction of the student between the notion of the topic and its cognitive experience of the game reunites the basic conditions for the learning from the manipulation of the micro worlds.

\section{RESULTS}

The study was developed following the assumptions of the pre-experimental experimental design with intact samples, evaluated before and after the 50 students of the Faculty of Education distributed in five professional schools.

During the experimentation, it was possible to identify the conceptual changes acquired during the interaction with the micro world, which evidenced the detachment, the interest in formalizing their random experiments, the obtaining of the sample spaces and the operations with events. The operations of these have awakened the formalizations in the presentation of the probabilities, the identification and understanding of axioms, resolution and interpretation of results of the probabilities.

The following are the results before and after the experimentation in reference to the achievements of the twenty-first century learning of the topic of probabilities.

Figure 1. Comparative chart of pre and post- test grades by vocational school.

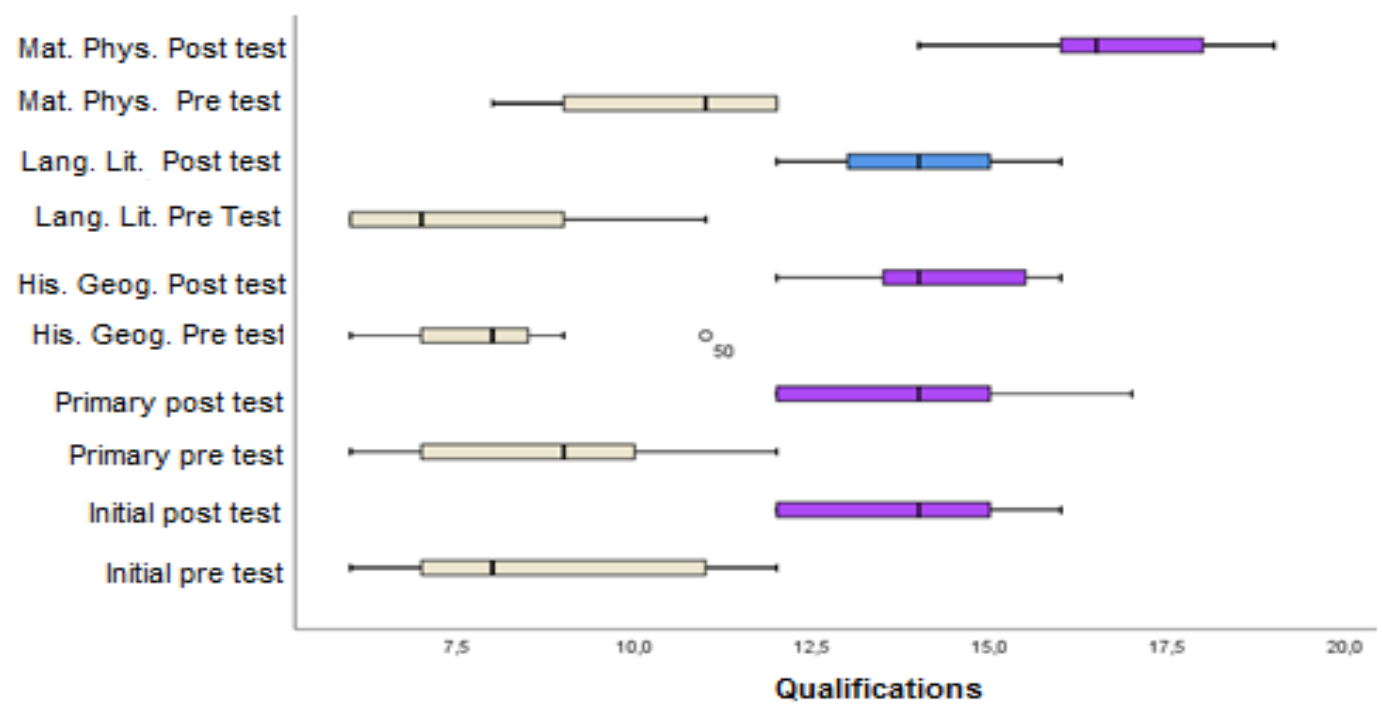

Source: The authors (2020).

The box and whiskers diagram shows the comparisons between the results of the scores obtained by the evaluation instrument of an objective test before and after. The academic results obtained in the pre-test for students in the History and Geography vocational school (EP) are shown, which are not very dispersed in comparison to the other schools. 
The grades of the students of the PD of initial education and of primary education present greater interquartile range. After experimentation, the plots representing the grade scores are above the pre-test plots, implying that the use of micro-worlds had an effect on learning the probability topic.

The post-test diagrams of early childhood, elementary, history and geography, and language arts professional schools show similar behavior as the Math and Physics PD diagram that is above all the diagrams in comparison to the quartiles. However, it is observed that there is a significant difference between the results of the two tests with improvement in the post test, which was thanks to the use and manipulation in the micro world scenarios.

Table 1. Statistics and parameters of academic achievement between the pre and post- test.

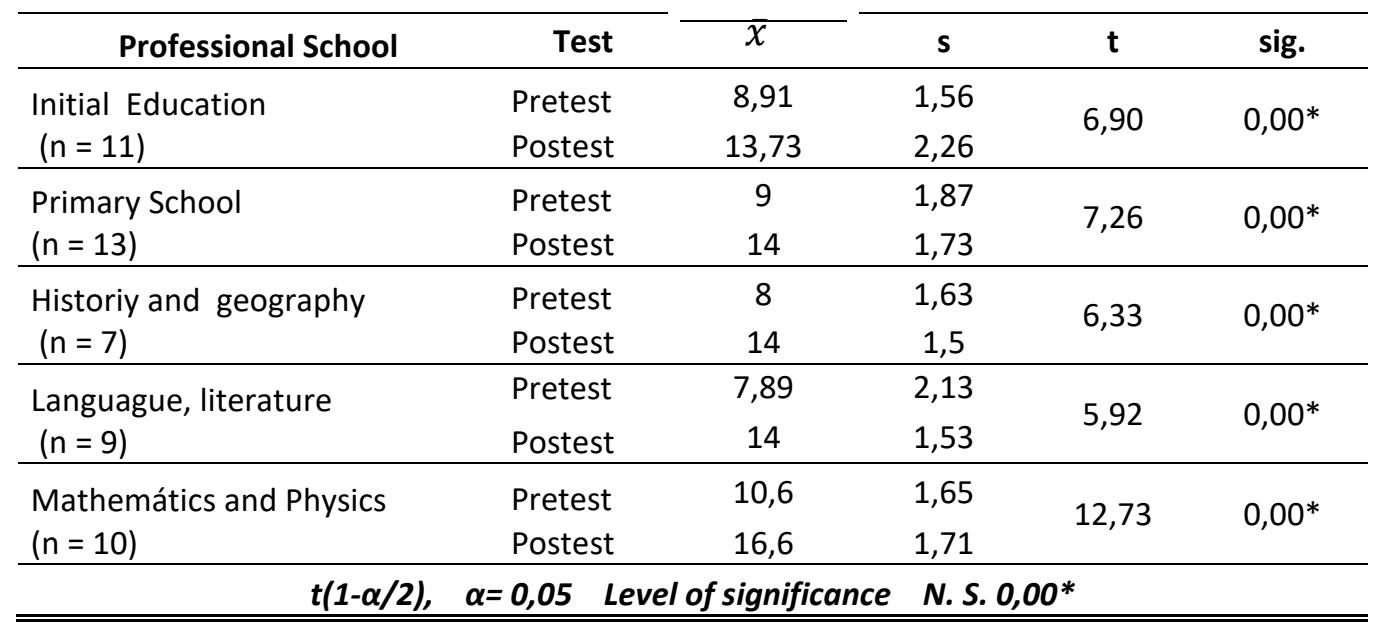

The statistical results in the table show the comparisons of the averages between the pretest and the post-test of the students of the different professional schools of the faculty of education. In this regard, the eleven students of the professional school of Early Education present a mean and standard deviation of $8.91 ; 1.56$ and $13.73 ; 2.26$ in the pre-test and post-test respectively, which allowed obtaining a statistical result of $t$ Student equal to 6.90 at a statistical significance level of 0.05 compared to the significance value of 0.00 .

This comparison allows affirming that the use and manipulation of micro-worlds as a learning strategy improves the understanding of the topic of classical probabilities; moreover, it is necessary to recognize that it was these students who showed their most developed scenarios with different thematic details.

With respect to the students of primary education, the comparative results of the means and deviation between pre and post-test after the use of the micro worlds allowed the improvement of the learning of the probabilities, detected by the comparison of the $p$ value $<0.05$.

In this regard, Manterola et al. (2008) indicate that statistical significance is related to test the hypothesis in comparison with the value of statistical significance. In addition, it should be noted that it was the group that showed more passion and enthusiasm in the presentation of their microworlds; the objects presented were very varied in different scenarios, such as rockets in the universe, movements of stars, growth of plants, among others, allowing them to simulate the theme of probabilities.

While the students of the professional schools of History and Geography and the students of the professional school of Language and Literature presented similar academic achievements among the means and deviations as visualized in the table, it was also detected that the use of the micro worlds strengthened the learning of the probabilities. 
Finally, the results of the Math and Physics PE students presented greater conceptual enjoyment of the topic, obtaining the highest average in the post test compared to the averages of the other schools. Due to their affinity to their professional training, they showed more initiative in the conceptual field, they moved away a little bit from the details in terms of form; the presentation of the objects was more detailed in the programming of the displacements and the determinations of the probabilities in varied cases of the events. The comparison of the value $p<0.05$ allows affirming that the interaction with the micro-worlds improves the learning of the topic of probabilities.

\section{DISCUSSION}

The interaction with micro-worlds in the learning process is considered a strategy for the student that allows to promote and understand the behavior of the axioms of the topic of probabilities; however, in the SM project of Noss \& Hoyles (2019) extreme reactions of susceptibility are identified at the beginning of the experience that allows the teacher to get involved in new competences, awakening the collaborative, interactive and flexible learning for the access to information.

These findings evidence the change of learning paradigm by the student of the different professional schools and for the teacher new ways of teaching, under this learning strategy, the student is the one who builds his learning in a free, spontaneous way with established purposes as it is the case in the topics of the probabilities. In these forms of learning, the students promoted competences and abilities like classifying, representing the conclusions, arguing the procedures of the solution of probabilities and responding to the solution of exercises and problems referring to the probabilities, in the findings of Giraldo et al. (2015), the interactive micro worlds respond to the tasks of planning and verification during the control of the processes of effective communication between the developers and users.

The strategic interactive use of micro-worlds allowed improving the learning of the topic of probabilities and evidenced its practical and significant application in everyday life, since it is common that we frequently perceive and issue appreciations of uncertainties to various events and concrete facts that explain their existence, as stated by Ciro et al. (2010).

The micro-worlds interface provides the student with an easy way to manipulate and shows attraction to simulate dynamically constructed phenomena. This experimentation generates mental models, and also allows the evaluation of real-world skills. These arguments are corroborated with the findings in the study, by promoting mathematical logical thinking, creativity, socialization, selection and discrimination of objects according to their environment presented in different scenarios.

For their part, Macías \& Duarte (2018) stated that the use of educational media allows for the complexity of learning processes that are inherent to the demands of each learning subject, which allows for the manipulation of specific materials, or the programming of experiential situations on the computer using software in different scenarios with algorithmic content in terms of probability, in addition to its practical elaboration, with a predominance of heuristics for each selected element.

During the process of elaboration, it has been evidenced the self-learning in the experienced topic, besides the exploration between the trial and error in the programming under a defined logic of learning. This interaction allows the student to assume a playful attitude during the learning process because of its high interactivity during the elaboration, as stated by Viteri et al. (2011).

The elaboration of micro worlds allows the insertion of the planned games in the learning process. This demonstrated skills and strengthened logical mathematical thinking. Its elaboration allows an adequate design of recreation of real worlds in computer-assisted environments; these 
designs present a high level of interactivity and allow the student to learn while playing according to his/her experience and interest.

With reference to the games, Molina (2016) affirms that it gains more strength in the numerical calculations, since it is the incentive for the motivation and initiation to the mathematical contents. During the experimentation, the students of the professional school of Initial Education showed greater motivation during its elaboration, in addition they managed to understand the concepts of the probabilities in spite of its abstract complexity.

It has been detected, while the student elaborates his scenarios for the learning of the probabilities that they wake up interest and motivation predisposing a suitable environment for the acquisition of the concepts. In the study of Viteri et al. (2011) it has been detected that micro-worlds are tools with constructivist support, they simulate the real and objective world from where the student shows interactivity with the objects, the student is the one who works, programs and analyzes the procedures in a rational way, they learn in the trial and error the programming that allows to simulate the competences to determine the probabilities. As a result of the described experiences, it is propitious to recommend the use of technology for learning in diverse contents of different curricular experiences to benefit the students' learning.

During the elaboration of the micro worlds, the students have the diverse objects and tools, according to their concepts of the objects, they elaborated by own initiative with the slogan to show the concepts of the probabilities and to understand their utility. Under these arguments, the student is the one who programs according to his logic for the obtaining of diverse concepts of the probabilities; it is so the student constructs his learning for his own interest.

In this respect, Osorio \& Ramírez (2020) conclude that learning revolves around the activity of the student who learns in a playful way, since the errors committed are part of the process arriving at desired slogans. The strategic use of the interactive micro-world allows for evidence of academic achievement, and constitutes a very powerful pedagogical resource that awakens motivation in students

\section{CONCLUSION}

The experimentation with micro-worlds as active strategies of learning based on the theory of constructionism presents a high degree of interactivity associated with sounds, silhouettes, graphics and activities; it also allows promoting the conceptualization and resolution of exercises and problems of the topic of probabilities in an experiential way in natural environments simulated by the computer. Besides, it was evidenced the detachment of the mathematical logical thought, the creativity and the socialization during its elaboration, which were incentives for the significant construction of the probabilistic thought as part of the statistical culture.

\footnotetext{
Authors' Contributions:

Angel Salvatierra Melgar: Conception and design, analysis and interpretation of data. José Nieto Gamboa: acquisition of data, critical review of important intellectual content. César Daniel Escuza Mesías: acquisition of data, critical review of important intellectual content. Paola Gissella Orozco-Vargas: drafting the article, critical review of important intellectual content. Linda Shardin-Flores: Critical review of important intellectual content. All authors have read and approved the final version of the manuscript.
}

Ethics Approval: Not applicable.

Acknowledgments: Not applicable. 


\section{REFERENCES}

Alava Viteri, C., Aguirre Cabrera, A., Cabrera Meza, H. E., Campaña Bastidas, S. E., \& Maya, J. A. (2011). Creación de micromundos aplicando la teoría de juegos y el diseño orientado a objetos. Revista de Investigaciones UNAD, 10(1), 185-195. https://doi.org/10.22490/25391887.746

Badilla Saxe, E., \& Chacón Murillo, A. (2011). Construccionismo: objetos para pensar, entidades públicas y micromundos. Revista Actualidades Investigativas en Educación, 4(1), 1-12. https://doi.org/10.15517/aie.v4i1.9048

Bedoya Osorio, V., \& Carmona Ramírez, L. H. (2020). Validación de un micromundo para la enseñanza de las matemáticas en un contexto rural. Revista Espacios, 41(28), 290-300.

Cabrera, P. (2011). ¿Qué debe saber y saber hacer un profesor de estudiantes con talento académico? Una propuesta de estándares de formación inicial en educación de talentos. Estudios Pedagógicos, 37(2), 43-59.

http://dx.doi.org/10.4067/S0718-07052011000200002

Duque Álvarez, S. G., Castro, D. A., \& Jaén Posada, S. (2015). Micromundos: una herramienta de enseñanzaaprendizaje en Ingeniería. Revista Educación en Ingeniería, 10(20), 23-34. https://doi.org/10.26507/rei.v10n20.556

García Molina, M. (2016). Probabilidad e incertidumbre, una aproximación desde la historia del pensamiento. Revista de Economía Institucional, 18(35), 101-122. https://doi.org/10.18601/01245996.v18n35.06

Grisales Aguirre, A. (2018). Uso de recursos TIC en la enseñanza de las matemáticas: retos y perspectivas. Entramado, 14(2), 198-214. https://doi.org/10.18041/1900-3803/entramado.2.4751

Jiménez, A., \& Gutiérrez, A. (2017). Realidades escolares en las clases de matemáticas. Educación Matemática, 29(3), 109-129. https://doi.org/10.24844/em2903.04

Londoño Ciro, L. A., Castro Castro, C. A., Jiménez Builes, J. A., \& Pérez Patiño, A. L. (2010). Uso de micromundos con dinámica de sistemas y lógica difusa para el diseño de evaluzación de competencias en ciencias básicas en ingeniería.

Manterola D. , Carlos; Pineda N., Viviana; Grupo Mincir. (2008). El valor de «p» y la «significación estadística». Aspectos generales y su valor en la práctica clínica. Revista Chilena de Cirugía, 60(1), 86-89.

https://doi.org/10.4067/S0718-40262008000100018

Marín Giraldo, Y., Posada Silva, W. Y., García Duque, B., \& Munévar Molina, R. A. (2015). Metodología para la creación de micromundos interactivos. Revista Kepes, 12(11), 61-81. https://doi.org/10.17151/kepes.2015.12.11.4

Munévar Quintero, F. I. (2009). Creación de un micromundo interactivo en una institución educativa rural. Revista Latinoamericana de Estudios Educativos, 5(1), 155-177.

Muñoz Camacho, S., Gallardo, T., Muñoz Bravo, M., \& Muñoz Bravo, C. A. (2018). Probabilidad de deserción estudiantil en cursos de matemáticas básicas en programas profesionales de la Universidad de Los Andes-Venezuela. Formación Universitaria, 11(4), 33-42. http://dx.doi.org/10.4067/s0718-50062018000400033

Noss, R., \& Hoyles, C. (2019). Micromundos, construccionismo y matemáticas. Educación Matemática, 31(2), 7-21. https://doi.org/10.24844/EM3102.01

Nascimento, L. F. do, \& Cavalcante, M. M. D. (2018). Abordagem quantitativa na pesquisa em educação: investigações no cotidiano escolar. Revista Tempos E Espaços Em Educação, 11(25), 249-260.

https://doi.org/10.20952/revtee.v11i25.7075

Ospina Tascón, V. L. (2016). El docente del nivel inicial: retos para la formación profesional y continua. Revista Educación y Humanismo, 18(30), 107-122. https://doi.org/10.17081/eduhum.18.30.1325

Oliveira, E. S., \& Barreto, D. A. B. (2020). Contemporary studies on knowledge, teaching in higher education and social representations in Brazil. Journal of Research and Knowledge Spreading, 1(1), e11585.

http://dx.doi.org/10.20952/jrks1111585

Papert, S. (1995). La máquina de los niños: replantearse la educación en la era de los ordenadores. Barcelona: Paídos.

Restrepo B., L. F., \& González L., J. (2003). La historia de la probabilidad. Revista Colombiana de Ciencias Pecuarias, 16(1), 83-87.

Ruiz Macías, E., \& Duarte, J. E. (2018). Diseño de un material didáctico computarizado para la enseñanza de oscilaciones y ondas, a partir del estilo de aprendizaje de los estudiantes. RIDI: Revista de Investigación, Desarrollo e Innovación, 8(2), 295-309. https://doi.org/10.19053/20278306.v8.n2.2018.7966 
Santos, I. T. R., Barreto, D. A. B., \& Soares, C. V. C. O. (2020). Formative assessment in the classroom: the dialogue between teachers and students. Journal of Research and Knowledge Spreading, 1(1), e11483.

https://doi.org/10.20952/jrks1111483

Silva, F. O., Alves, I. S., \& Oliveira, L. C. (2020). Initial teaching training by homology in PIBID: experiential learning from professional practice. Journal of Research and Knowledge Spreading, 1(1), e11638.

http://dx.doi.org/10.20952/jrks1111638

Silva, C. V. S., \& Santos, G. O. (2020). Digital interfaces: a methodological proposal as a strategy of teaching and learning in Mathematics classes. Journal of Research and Knowledge Spreading, 1(1), e11651.

https://doi.org/10.20952/jrks1111651

Vásquez Ortiz, C., \& Alsina, Á. (2017). Lenguaje probabilístico: un camino para el desarrollo de la alfabetización probabilística. Un estudio de caso en el aula de educación primaria. Bolema: Boletim en Educação Matemática, 31(57), 454-478. http://dx.doi.org/10.1590/1980-4415v31n57a22

Zurita Cruz, J. N., Márquez González, H., Miranda Novales, G., \& Villasis Keever, M. Á. (2018). Estudios experimentales: diseños de investigación para la evaluación de intervenciones en la clínica. Revista Alergia México, 65(2), $178-186$.

https://doi.org/10.29262/ram.v65i2.376

Received: 06 October 2020 | Accepted: 10 January 2021 | Published: 21 January 2021

This is an Open Access article distributed under the terms of the Creative Commons Attribution License, which permits unrestricted use, distribution, and reproduction in any medium, provided the original work is properly cited. 